\title{
Epiglottic aplasia in an infant with Joubert syndrome
}

\author{
Lindsey Shehee (1) , Jaye Downs, Clarice Clemmens
}

Otolaryngology, Medical

University of South Carolina,

Charleston, South Carolina, USA

\section{Correspondence to \\ Dr Lindsey Shehee; \\ shehee@musc.edu}

Accepted 17 October 2020

\begin{abstract}
SUMMARY
Congenital aplasia of the epiglottis is a rare condition with variable presentation ranging from respiratory distress requiring surgical airway to an asymptomatic finding. Epiglottic aplasia is presumed to be caused by arrest of development of laryngeal structures and is most commonly associated with syndromic conditions, though isolated episodes of aplasia of the epiglottis do exist. In this report, we present a term infant with multiple congenital anomalies who was noted to have a hoarse cry prompting laryngoscopy. This showed complete absence of the epiglottis. Subsequent genetic testing showed mutations in the CPLANE1 gene that is associated with Joubert syndrome. Our patient was able to be discharged home on a thickened formula diet and is eating and gaining weight appropriately. Here, we present a review of the currently available literature of other cases of congenital epiglottic aplasia or hypoplasia discussing the presentation, management and outcomes in these cases.
\end{abstract}

\section{BACKGROUND}

Congenital abnormalities of the larynx are rare and are often associated with anomalies of multiple other organ systems and other areas of the upper aerodigestive tract. Primordial functions of the larynx include airway protection with phonation being a later adaptation. ${ }^{1}$ Abnormalities of the supraglottis are common causes of respiratory distress and feeding difficulties in children with the most common abnormality being laryngomalacia. ${ }^{1}$ Other anomalies including congenital laryngeal stenoses and atresia are significantly less common. We report the case of a neonate born at term with multiple prenatally diagnosed congenital anomalies. Postnatally, she developed stridor and was noted to have a hoarse cry ultimately leading to the diagnosis of aplasia of the epiglottis.

\section{CASE PRESENTATION}

Our patient was born at term to a 34-year-old G2P2002 mother. She had multiple prenatally diagnosed abnormalities including a large atrial septal defect, Dandy-Walker malformation, polydactyly of both feet and the right hand, syndactyly of bilateral feet, dysconjugate gaze, a soft tissue mass on the floor of the mouth and hypotonia. She was originally managed in the newborn nursery but was transferred to higher level of care due to persistent hypoglycaemic. The patient initially did well with oral feeds but began to have difficulty taking in adequate volumes on day of life (DOL) 3 when she began having increased work of breathing and desaturations with feeds. Over the next several days, the primary team and nursing staff noticed intermittent stridor with feeding attempts as well as a hoarse cry for which the otolaryngology team was consulted. Bedside flexible fiberoptic nasolaryngoscopy revealed gross abnormalities including absent epiglottis and hypertrophic arytenoids with diminutive interarytenoid area. The vocal folds demonstrated full adduction and abduction. The patient was subsequently taken to the operating room on DOL 15 for formal microlaryngoscopy and bronchoscopy where the above findings were again confirmed (figure 1). The remainder of the airway examination including the glottis, subglottis, trachea and mainstem bronchi were without abnormalities.

\section{DIFFERENTIAL DIAGNOSIS}

On initial evaluation of this patient, she was noted to have a hoarse cry but with no audible stridor. The differential diagnosis based on this finding was broad but included unilateral vocal fold paralysis, birth-related trauma causing vagal nerve injury, anatomic abnormality such as laryngeal web or reflux. Bilateral vocal fold paralysis was considered given her stridor and increased work of breathing. In addition, central neurological causes were considered given her known congenital brain abnormalities. Ultimately, diagnosis was confirmed after laryngoscopy showed bilaterally mobile vocal folds with no additional anomalies aside from the absence of the epiglottis.

\section{TREATMENT}

Speech and language pathology was consulted for evalution of stridor with feeds and dysphagia. A

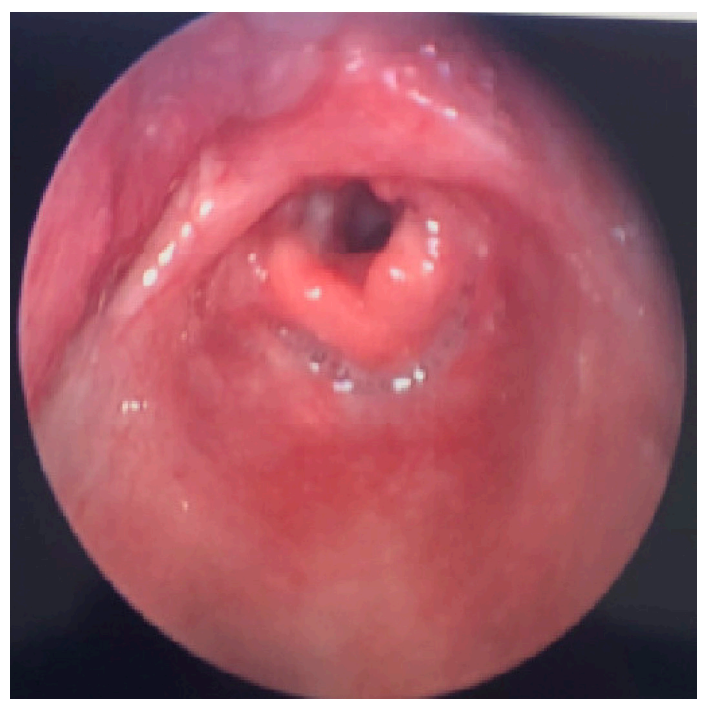

Figure 1 Intraoperative photo from direct laryngoscopy showing absent epiglottis, hypertrophied arytenoids with diminutive interarytenoid Notch. 


\begin{tabular}{|c|c|c|c|}
\hline Study & Presentation & Management & Outcome \\
\hline Bonilla et al' & $\begin{array}{l}\text { Inspiratory stridor at birth. Multiple other congenital anomalies including subglottic stenosis, but no recognised } \\
\text { syndrome. }\end{array}$ & $\begin{array}{l}\text { Initially discharged home on oral } \\
\text { feeds. Tracheostomy at } 2 \text { years for } \\
\text { sleep apnoea. }\end{array}$ & $\begin{array}{l}\text { Decannulated at } 7 \text { years } \\
\text { with no sequelae of } \\
\text { sleep apnoea, aspiration } \\
\text { or failure to thrive. }\end{array}$ \\
\hline $\begin{array}{l}\text { Constantinides and } \\
\text { Cywes }^{9}\end{array}$ & Complete median mandibular cleft with aplasia of the epiglottis. & $\begin{array}{l}\text { Persistent aspiration requiring } \\
\text { tracheostomy and gastrostomy } \\
\text { tube. }\end{array}$ & $\begin{array}{l}\text { Died a few weeks } \\
\text { after birth due to } \\
\text { anoxic episode } \\
\text { from tracheostomy } \\
\text { obstruction. }\end{array}$ \\
\hline Aikaterini and Dritsoula ${ }^{14}$ & Term male neonate with stridor and difficulty with oral feeds. No other congenital anomalies noted. & $\begin{array}{l}\text { Fundoplication and percutaneous } \\
\text { endoscopic gastrostomy placed at } \\
7 \text { weeks for persistent aspiration. }\end{array}$ & $\begin{array}{l}\text { Maintained on total } \\
\text { gastrostomy tube feeds } \\
\text { at age } 11 \text { months. }\end{array}$ \\
\hline Hall et all ${ }^{15}$ & $\begin{array}{l}\text { Six cases of hypothalamic hamartoblastoma, postaxial polydactyly, and imperforate anus with hypopituitarism and } \\
\text { hypoadrenalism reported. Of these, two had aplasia of the epiglottis. }\end{array}$ & N/A & Neonatally lethal \\
\hline Holinger and Brown ${ }^{16}$ & $\begin{array}{l}\text { Report of } 657 \text { patients with laryngeal anomalies, two of which had complete aplasia. Both also had severe } \\
\text { subglottic stenosis. }\end{array}$ & N/A & N/A \\
\hline Hong and Yang ${ }^{11}$ & $\begin{array}{l}\text { 20-year-old with voice hoarseness and frequent throat clearing. Examination showed aplasia of the epiglottis and } \\
\text { false vocal folds. Also with bilateral maxillary hypoplasia. }\end{array}$ & None required & $\begin{array}{l}\text { Mild voice hoarseness } \\
\text { and throat clearing, no } \\
\text { functional deficits. }\end{array}$ \\
\hline Demir $^{17}$ & 10 months man with Pierre Robin Sequence admitted with aspiration pneumonia & $\begin{array}{l}\text { Nasogastric tube feeds initiated } \\
\text { and followed a swallow } \\
\text { rehabilitation programme. }\end{array}$ & $\begin{array}{l}\text { Swallowing function } \\
\text { improved by } 12 \text { months } \\
\text { of age. }\end{array}$ \\
\hline Kim et $a l^{4}$ & Isolated epiglottic aplasia found incidentally in an asymptomatic 33-year-old woman. & $\begin{array}{l}\text { Modified swallow study showed } \\
\text { compensation from lingual tonsils } \\
\text { and base of tongue for airway } \\
\text { closure with no aspiration. }\end{array}$ & $\begin{array}{l}\text { Asymptomatic with no } \\
\text { functional deficits. }\end{array}$ \\
\hline Koempel $^{6}$ & Term male who presented at 3 months with respiratory distress and mild stridor. No other congenital anomalies. & $\begin{array}{l}\text { Underwent fundoplication and } \\
\text { gastrostomy tube placement at } 4 \\
\text { months of age for aspiration. }\end{array}$ & $\begin{array}{l}\text { At } 17 \text { months of age, } \\
\text { no further respiratory } \\
\text { problems. Had not } \\
\text { yet tried to vocalise. } \\
\text { Remained gastrostomy } \\
\text { tube dependent. }\end{array}$ \\
\hline Lu et $a l^{18}$ & Male neonate with tricho-rhino-phalangeal syndrome type II in addition to aplasia of epiglottis. & N/A & $\begin{array}{l}\text { Died at } 11 \text { days of } \\
\text { age due to renal and } \\
\text { respiratory failure. }\end{array}$ \\
\hline Meinecke and Hayek ${ }^{19}$ & Male infant with multiple congenital anomalies consistent with orofaciodigital syndrome type IV. & N/A & Died shortly after birth. \\
\hline Prasad $^{20}$ & Series of six infants with epiglottic aplasia presenting with acute life-threatening events. & $\begin{array}{l}\text { Five of six managed with } \\
\text { temporary supraglottic suture } \\
\text { closure and tracheostomy } \\
\text { while pharyngo-oesophageal } \\
\text { coordination was being } \\
\text { established. }\end{array}$ & $\begin{array}{l}\text { One died prior to } \\
\text { undergoing supraglottic } \\
\text { closure. Remaining } \\
\text { five had reversal of } \\
\text { supraglottic closure and } \\
\text { are doing well. }\end{array}$ \\
\hline Reyes et $a l^{21}$ & $\begin{array}{l}\text { Presented at } 3 \text { months with stridor. Over the next } 8 \text { years, developed severe sleep apnoea. No other anomalies } \\
\text { noted. }\end{array}$ & $\begin{array}{l}\text { At } 8 \text { years of age, sleep apnoea } \\
\text { being managed with lifestyle } \\
\text { changes. }\end{array}$ & N/A \\
\hline Vaibhav Shahi ${ }^{13}$ & $\begin{array}{l}\text { A } 30 \text {-year-old woman diagnosed incidentally during intubation for an unrelated procedure. Noted to also have } \\
\text { subglottic stenosis. No other anomalies. }\end{array}$ & None required & Asymptomatic \\
\hline Tay et $a l^{10}$ & $\begin{array}{l}\text { Series of two patients with Nager syndrome: } \\
\text { A 3-year-old girl with aspiration with feeds, prior tracheostomy for mandibular hypoplasia. } \\
\text { An 18-month-old girl with aspiration and recurrent respiratory infections. }\end{array}$ & $\begin{array}{l}\text { A 3-year-old girl had prior } \\
\text { tracheostomy tube placement. } \\
\text { Maintained on nasogastric tube } \\
\text { feeds. } \\
\text { An } 18 \text {-month-old girl had } \\
\text { gastrostomy tube placement at } 5 \\
\text { months of age. }\end{array}$ & $\begin{array}{l}\text { Further follow-up not } \\
\text { available. }\end{array}$ \\
\hline Weerasinghe et $a^{22}$ & A 2-year-old boy with multiple congenital anomalies and bronchiectasis due to chronic aspiration events. & $\begin{array}{l}\text { Managed on prophylactic } \\
\text { macrolide therapy and chest } \\
\text { physiotherapy. Maintains a normal } \\
\text { diet with swallowing therapy. }\end{array}$ & $\begin{array}{l}\text { Progressing well at } 4 \\
\text { years of age. }\end{array}$ \\
\hline
\end{tabular}

N/A, not available.

modified barium swallow study revealed intratracheal aspiration with thin liquids and laryngeal penetration with nectar thick liquids. She was transitioned to a nectar thickened consistency which she tolerated, though with increased feeding time. She was ultimately discharged home on DOL 18 tolerating full oral feeds with nectar thick consistency.

\section{OUTCOME AND FOLLOW-UP}

At the time of discharge, she was gaining weight appropriately and was tracking along the 66th percentile for weight. At her last follow-up appointment with otolaryngology, she was continuing to gain weight appropriately and was at the 54th percentile for weight. She was continuing to follow her nectar thick consistency diet. Genetic testing was performed given her multiple congenital anomalies. Whole-exome sequencing revealed mutations in the CPLANE1 gene that is associated with autosomal recessive Joubert syndrome. ${ }^{2}$ This condition is associated with midbrain and hindbrain abnormalities, developmental delay, hypotonia, breathing abnormalities, syndactyly, polydactyly and atypical eye movements. ${ }^{2}$ A review of the literature reveals only once case of Joubert syndrome associated with epiglottic anomalies. Sung et al report a case of a 2-year-old boy with episodic respiratory distress and stridor. Laryngoscopy revealed absence of the right half of the epiglottis and severe hypoplasia of the left half. ${ }^{3}$ Of note, our patient's mother has epilepsy and took oxcarbazepine 
Table 2 Cases of congenital hypoplasia of the epiglottis

\begin{tabular}{|c|c|c|c|}
\hline Study & Presentation & Management & Outcome \\
\hline Arya et $a l^{23}$ & Lethal case of a female with $G$ syndrome with multiple anomalies including epiglottic and laryngeal hypoplasia. & N/A & Stillborn \\
\hline Azar et al ${ }^{8}$ & Term male born with lacrimo-auriculo-dental-digital syndrome. In addition, noted to have hypoplastic epiglottis. & $\begin{array}{l}\text { Difficult intubation at birth. Required } \\
\text { tracheostomy and gastrostomy tube } \\
\text { placement for aspiration. }\end{array}$ & $\begin{array}{l}\text { Remains tracheostomy and } \\
\text { gastrostomy tube dependent at } \\
5 \text { years. }\end{array}$ \\
\hline Benjamin and Dalton ${ }^{24}$ & Term infant who developed stridor shortly after birth. Associated with possible velocardiofacial syndrome. & $\begin{array}{l}\text { Due to reflux and aspiration, underwent } \\
\text { fundoplication and gastrostomy tube } \\
\text { placement. }\end{array}$ & Long-term outcome unknown. \\
\hline Chen et $a^{25}$ & $\begin{array}{l}\text { Term infant with short rib-polydactyly syndrome type } 2 \text { (Majewski) as well as multiple extraskeletal anomalies } \\
\text { including malformed larynx and hypoplastic epiglottis. }\end{array}$ & N/A & $\mathrm{N} / \mathrm{A}$ \\
\hline D'Antonio et al ${ }^{26}$ & A series of 23 patients with oculo-auriculo-vertebral syndrome who also had abnormalities of the epiglottis. & N/A & N/A \\
\hline Hayes et $a^{27}$ & $\begin{array}{l}\text { Term infant with orofaciodigital syndrome type } \mathrm{VI} \text { as well as rudimentary epiglottis, U-shaped arytenoids with } \\
\text { no interarytenoid space, absent aryepiglottic folds. }\end{array}$ & $\begin{array}{l}\text { Intubated at birth, gastrostomy tube } \\
\text { placed. }\end{array}$ & $\begin{array}{l}\text { Remains gastrostomy tube } \\
\text { dependent. }\end{array}$ \\
\hline Karaman and Kahveci ${ }^{28}$ & Term male born with multiple maxillofacial and limb anomalies. & Not reported & Not reported \\
\hline Knapp et al ${ }^{7}$ & 3 day old infant with short rib polydactyly syndrome, Majewski type. & Intubated at birth & $\begin{array}{l}\text { Died at } 47 \text { days of life due to } \\
\text { respiratory complications }\end{array}$ \\
\hline Krauss et a $\left.\right|^{29}$ & $\begin{array}{l}\text { Term infant with Nager syndrome and multiple additional anomalies including syndactyly, hypoplastic first rib, } \\
\text { dislocated right hip, laryngeal and epiglottic hypoplasia. }\end{array}$ & Intubated at birth & Died of respiratory failure \\
\hline Li et $a l^{30}$ & Male infant with Pierre Robin sequence and feeding difficulties. Did not develop respiratory distress. & $\begin{array}{l}\text { Tracheostomy performed at } 4 \text { months of } \\
\text { age. Feeds provided by nasogastric tube. }\end{array}$ & $\begin{array}{l}\text { Furlow palatoplasty performed at } \\
7 \text { months of age. At that time, still } \\
\text { receiving nasogastric feeds. }\end{array}$ \\
\hline Shwan Mohamad et al' ${ }^{12}$ & $\begin{array}{l}\text { Asymptomatic 50yo female presenting with oral ulcers. Hypoplastic epiglottis found incidentally on } \\
\text { laryngoscopy. }\end{array}$ & N/A & Asymptomatic \\
\hline $\operatorname{Roh}^{5}$ & 42yo male with mild hoarseness and throat discomfort. No other anomalies. & $\begin{array}{l}\text { Laryngopharyngeal reflux noted on } \\
24 \text { hours } \mathrm{pH} \text { monitoring. Treated } \\
\text { with lifestyle changes and antireflux } \\
\text { medications. }\end{array}$ & $\begin{array}{l}\text { Symptoms improved. Otherwise } \\
\text { asymptomatic. }\end{array}$ \\
\hline Rizk et $a^{31}$ & $\begin{array}{l}\text { Term male with feeding difficulties since birth and multiple admissions for aspiration pneumonia. Diagnosed at } \\
26 \text { months of age. No other congenital anomalies. }\end{array}$ & $\begin{array}{l}\text { Fundoplication and gastrostomy tube } \\
\text { placement performed. }\end{array}$ & N/A \\
\hline Visveshwara et $a^{32}$ & Male infant with a syndrome associated with accelerated skeletal maturation and rudimentary epiglottis. & N/A & $\mathrm{N} / \mathrm{A}$ \\
\hline
\end{tabular}

$\mathrm{N} / \mathrm{A}$, not available.

through the duration of pregnancy. The genetics team believes in utero exposure to this medication may have also contributed to our patient's congenital anomalies as they cannot all be explained by Joubert syndrome. A review of the literature to date does not reveal any prior publications linking in utero exposure to congenital epiglottic anomalies.

\section{DISCUSSION}

Congenital absence of the epiglottis is an exceedingly rare condition and is most commonly described in the setting of syndromic conditions. Less commonly, case reports of isolated epiglottic aplasia have been reported. Manifestations of aplasia or hypoplasia of the epiglottis can vary significantly from some patients being completely asymptomatic, to mild voice changes to early life-threatening dyspnoea requiring tracheostomy tube placement. ${ }^{45}$ A summary of previously published reports of congenital aplasia (table 1) or hypoplasia of the epiglottis (table 2) and overall outcomes of the involved patients are reported below.

The function of the epiglottis remains controversial. While many believe it plays a role in protecting the airway while swallowing, some studies have shown that it plays a minor role when compared with the true and false vocal cords in airway protection. In addition, case series have shown that adult patients undergoing epiglottectomy for oncological purposes initially developed mild aspiration postoperatively, but this universally resolved after only a few days of speech therapy. ${ }^{6}$ In our review of cases of congenital absence of the epiglottis, patients exhibit a range of symptom severity from respiratory distress at birth and severe aspiration pneumonia to being asymptomatic into adulthood with epiglottic absence being noted incidentally.

The embryologic development of the larynx is complex. The larynx first appears between days 25 and 28 gestation corresponding to Carnegie stage $10 .^{7}$ At this point, a thickening of the epithelium forms along the ventral foregut called the respiratory primordium. Around 33 days (Carnegie stage 15), the epiglottic swelling becomes visible in the region of the hypobranchial eminence. The epiglottis is readily identifiable by 41 days gestation and shortly after, demarcates from the base of tongue forming a concave configuration. By the 57 th gestational day, the features of the adult larynx are present, but the epiglottis remains unchondrified until the 5th month of gestational age. ${ }^{7}$ Arrest of development is likely responsible for aplasia and hypoplasia of the epiglottis. Given the fact that other aspects of the larynx are developing synchronously, additional anomalies of the larynx are common in patients with epiglottic anomalies. Thus, we recommend complete airway evaluation to assess for additional anomalies in patients noted to have congenital anomalies of the epiglottis. Interestingly, the hand plate appears at 33 days gestation around the same time that the epiglottis begins to form. This may explain the association between extremity

\begin{tabular}{lll}
\hline Table 3 & Cases of congenital epiglottic anomalies where patients required establishment of a surgical airway due to symptom severity \\
\hline Study & Presentation & Other congenital anomalies identified? \\
\hline $\begin{array}{l}\text { Constantinides and } \\
\text { Cywwes }^{9}\end{array}$ & $\begin{array}{l}\text { Complete median mandibular cleft with aplasia of the epiglottis. Infant had persistent aspiration } \\
\text { requiring tracheostomy tube placement and gastrostomy tube. }\end{array}$ & Yes, complete median mandibular cleft \\
${\text { Tay et } a l^{10}}_{\text {Azar } e t ~ a l^{8}}$ & $\begin{array}{l}\text { Infant with severe aspiration as well as mandibular hypoplasia requiring tracheostomy tube placement. } \\
\text { Infant requiring intubation at birth for respiratory distress and noted to have hypoplastic epiglottis. }\end{array}$ & Yes, lacrimo-auriculo-dental-digital syndrome \\
& Ultimately required tracheostomy and gastrostomy tube placement. & \\
\hline
\end{tabular}


Table 4 Cases of congenital epiglottic anomalies where patients required alternative means of enteral access due to dysphagia

\begin{tabular}{|c|c|c|}
\hline Study & Presentation & Other congenital anomalies identified? \\
\hline Constantinides et al $l^{9}$ & $\begin{array}{l}\text { Complete median mandibular cleft with aplasia of the epiglottis. Infant had persistent aspiration } \\
\text { requiring tracheostomy tube placement and gastrostomy tube. }\end{array}$ & Yes, complete median mandibular cleft \\
\hline $\begin{array}{l}\text { Aikaterini and } \\
\text { Dritsoula }^{14}\end{array}$ & Term male neonate with stridor and inability to tolerate oral feeds. Isolated epiglottic aplasia identified. & No \\
\hline Demir $^{17}$ & Developed aspiration pneumonia requiring nasogastric tube placement for feeds. & Yes, Pierre Robin sequence \\
\hline Koempel et a/ ${ }^{6}$ & $\begin{array}{l}\text { Term male with isolated epiglottic aplasia requiring gastrostomy tube placement at } 4 \mathrm{mo} \text { due to } \\
\text { persistent aspiration. }\end{array}$ & No \\
\hline Tay et $a l^{10}$ & Two children with persistent aspiration both requiring gastrostomy tube placement. & Yes, Nager syndrome \\
\hline Azar et al ${ }^{8}$ & $\begin{array}{l}\text { Infant requiring intubation at birth for respiratory distress and noted to have hypoplastic epiglottis. } \\
\text { Ultimately required tracheostomy and gastrostomy tube placement. }\end{array}$ & Yes, lacrimo-auriculo-dental-digital syndrome \\
\hline Benjamin and Dalton ${ }^{24}$ & Term infant with stridor, reflux, aspiration. Required gastrostomy tube placement. & Yes, Velocardiofacial syndrome \\
\hline Hayes et a $\left.\right|^{27}$ & $\begin{array}{l}\text { Term infant who presented with respiratory distress at birth requiring intubation. Ultimately required } \\
\text { gastrostomy tube placement. }\end{array}$ & Yes, orofaciodigital syndrome type VI \\
\hline Li et $a l^{30}$ & Term infant with feeding difficulties. Did not develop respiratory distress. & Yes, Pierre-Robin sequence \\
\hline Rizk et $a l^{\beta 1}$ & Term infant with feeding difficulties, recurrent aspiration pneumonia. & No \\
\hline
\end{tabular}

and epiglottic congenital anomalies as seen in our patient and others.

As detailed in tables 1 and 2, the presentation of patients with congenital epiglottic abnormalities is incredibly variable. While a majority of cases are associated with other congenital anomalies and defined syndromes, there are also additional reports of isolated cases of epiglottic aplasia and hypoplasia, some of which were discovered incidentally in adulthood. Table 3 details cases where infants presented with immediate stridor requiring intubation and ultimately tracheostomy tube placement with variable rates of decannulation with age. ${ }^{8-10}$ It should be noted in all of these cases that these infants also had additional congenital anomalies which possibly contributed to their initial critical condition. Almost universally when epiglottic anomalies were noted in infancy, the child exhibited feeding difficulties and required either gastrostomy tube placement, nasogastric tube placement or dietary modifications with thickened consistencies as in the case we present. Table 4 details cases where patients required alternative means of enteral access due to feeding intolerance related to their epiglottic anomalies. Feeding difficulty was a much more common manifestation in infants with congenital epiglottic anomalies and was associated with both syndromic and non-syndromic presentations. In contrast,

\section{Learning points}

- Congenital epiglottic aplasia and hypoplasia are rare anomalies with presentations that can range from asymptomatic to emergent respiratory distress requiring placement of a surgical airway.

- Infants with congenital epiglottic abnormalities do not inherently have respiratory difficulties, nor do they always require surgical intervention to secure a safe airway. Much more commonly, these infants require alternative means of enteral access due to dysphagia and aspiration

- The majority of cases of epiglottic aplasia and hypoplasia are associated with syndromic conditions. Patients with epiglottic aplasia should be evaluated for additional congenital anomalies.

- Patients with congenital epiglottic anomalies should have a complete swallowing evaluation to monitor for aspiration. Growth should be monitored closely, and alternate forms of enteral access should be obtained when necessary.
Hong, Kim, Mohamad, Roh and Shahi showed that patients with similar laryngeal anomalies can be relatively asymptomatic and unaffected by their epiglottic anomalies as these patients all presented in adulthood with minor complaints including throat clearing and mild hoarseness. ${ }^{4511-13}$ These patients all developed compensatory swallowing mechanisms and did not exhibit issues with aspiration.

In this report, we present the case of an infant with likely Joubert syndrome as well as in utero exposure to oxcarbazepine who was noted to have absence of the epiglottis shortly after birth. To our knowledge, only one report exists detailing a congenital epiglottic anomaly in a child with Joubert syndrome and no such reports exist regarding an association between oxcarbazepine and epiglottic anomalies. Our patient's presentation was relatively mild as she did not develop respiratory distress and was able to tolerate an oral diet with only slight modifications. This is in contrast to the majority of infants diagnosed with epiglottic anomalies at birth who require alternative means of enteral access. At the time of publication, our patient continues to do well with weight gain with no evidence of aspiration and no respiratory difficulties.

Contributors LS contributed primary authorship of the original manuscript as well as revisions of further drafts. JD contributed to conceptualisation of the project, production of tables and refinements of drafts. CC contributed to conceptualisation of the project, draft organisation and refinements of manuscript.

Funding The authors have not declared a specific grant for this research from any funding agency in the public, commercial or not-for-profit sectors.

Competing interests None declared.

Patient consent for publication Parental/guardian consent obtained.

Provenance and peer review Not commissioned; externally peer reviewed.

ORCID iD

Lindsey Shehee http://orcid.org/0000-0002-9834-8990

\section{REFERENCES}

1 Bonilla JA, Pizzuto MP, Brodsky LS. Aplasia of the epiglottis: a rare congenita anomaly. Ear Nose Throat J 1998;77:51-5.

2 CPLANE1 gene. Genetics home reference 2020.

3 Myung-Whun Sung J-WK, Kim KH. Bifid epiglottis associated with Joubert's Syndrome. Ann Otol Rhinol Laryngol 2001;110.

$4 \mathrm{Kim}$ YJ, Myung NS, Lee HJ, et al. A case of congenital aplasia of the epiglottis in an adult. Am J Otolaryngol 2014;35:673-5.

5 Roh J-L. Hypoplasia of the epiglottis in a middle-aged man. Eur Arch Otorhinolaryngol 2005;262:470-2.

6 Koempel LH JA. Case report. congenital absence of the epiglottis. Int J Pediatr Otorhinolaryngol 1998;45:237-41. 
7 Knapp CH, Santin-Hodges A, Cole RR. Laryngeal findings in short rib polydactyly syndrome: case report and embryological correlations. Laryngoscope 1990;100:579-82.

8 Azar T, Scott JA, Arnold JE, et al. Epiglottic hypoplasia associated with lacrimoauriculo-dental-digital syndrome. Ann Otol Rhinol Laryngol 2000;109:779-81.

9 Constantinides CG, Cywes S. Complete median cleft of the mandible and aplasia of the epiglottis. A case report. S Afr Med J 1983;64:293-4.

10 Tay SY, Loh WS, Lim TC. A case report of absent epiglottis in children with Nager syndrome: its impact on swallowing. Cleft Palate Craniofac J 2017;54:754-7.

11 Hong $\mathrm{KH}$, Yang YS. Agenesis of the epiglottis and false vocal folds with maxillary hypoplasia in an adult. J Laryngol Otol 2003;117:895-8.

12 Shwan Mohamad IK, Muddaiah A, et al. Epiglottic hypoplasia: a natural model for supraglottic laryngoplasy. J Coll Physicians Surg Pak 2015;24:528-9.

13 Vaibhav Shahi DKS. Asymptomatic absent epiglottis. Int J Anat Radio/ Surg 2015;3:945-6.

14 Aikaterini K, Dritsoula MST. Congenital aplasia/hypoplasia of the epiglottis - A case report and review of the literature 2015.

15 Hall JG, Pallister PD, Clarren SK, et al. Congenital hypothalamic hamartoblastoma hypopituitarism, imperforate anus and postaxial polydactyly--a new syndrome? Part I: clinical, causal, and pathogenetic considerations. Am J Med Genet 1980;7:47-74.

16 Holinger PH, Brown WT. Congenital webs, cysts, laryngoceles and other anomalies of the larynx. Ann Otol Rhinol Laryngol 1967;76:744-52.

17 Demir N. Swallowing therapy for a case of congenital absence of the epiglottis. Clin Exp Health Sci 2018;8:70-2.

18 Lu FL, Hou JW, Tsai WS, et al. Tricho-Rhino-Phalangeal syndrome type II associated with epiglottic aplasia and congenital nephrotic syndrome. J Formos Med Assoc 1997:96:217-21.

19 Meinecke P, Hayek H. Orofaciodigital syndrome type IV (Mohr-Majewski syndrome) with severe expression expanding the known spectrum of anomalies. J Med Genet $1990 ; 27: 200-2$.
20 Prasad GR. Congenital isolated agenesis of epiglottis presenting with acute lifethreatening event successfully managed by temporary supraglottic closure and tracheostomy. Int J Phonosurg Laryngol 2015;5:1-3.

21 Reyes BG, Arnold JE, Brooks LJ. Congenital absence of the epiglottis and its potential role in obstructive sleep apnea. Int J Pediatr Otorhinolaryngol 1994;30:223-6.

22 Weerasinghe $\mathrm{P}$, Thomas $\mathrm{R}$, Masters $\mathrm{B}$, et al. Bronchiectasis in the setting of aplasia of the epiglottis. Respirol Case Rep 2019;7:e00430.

23 Arya S, Viseskul C, Gilbert EF. The G syndrome--additional observations. Am J Med Genet 1980;5:321-4

24 Benjamin B, Dalton C. Hypoplasia of the epiglottis: case report and review. Int J Pediatr Otorhinolaryngol 1996;38:65-9.

25 Chen H, Yang SS, Gonzalez E, et al. Short rib-polydactyly syndrome, Majewski type. Am J Med Genet 1980;7:215-22.

26 D'antonio LL, Rice RD, Fink SC. Evaluation of pharyngeal and laryngeal structure and function in patients with oculo-auriculo-vertebral spectrum. Cleft Palate Craniofac J 1998;35:333-41

27 Hayes LL, Simoneaux SF, Palasis S, et al. Laryngeal and tracheal anomalies in an infant with oral-facial-digital syndrome type VI (Váradi-Papp): report of a transitional type. Pediatr Radiol 2008;38:994-8.

28 Karaman A, Kahveci H. Unusual acrofacial dysostosis with severe limb defects: a new syndrome. Genet Couns 2011;22:248-53.

29 Krauss LH CM, Gang DL. Brief clinical report: anomalies in an infant with Nager acrofacial dysostosis. Am J Med Genet 1985;21:761-4.

30 Li S-P, Fang T-J, Lee S-W, et al. A rudimentary epiglottis associated with Pierre Robin sequence. Int J Oral Maxillofac Surg 2006;35:668-70.

31 Rizk HG, Nassar M, Rohayem Z, et al. Hypoplastic epiglottis in a non-syndromic child: a rare anomaly with serious consequences. Int J Pediatr Otorhinolaryngol 2010;74:952-5.

32 Visveshwara N, Rudolph N, Dragutsky D. Syndrome of accelerated skeletal maturation in infancy, peculiar facies, and multiple congenital anomalies. J Pediatr 1974;84:553-6.

Copyright 2020 BMJ Publishing Group. All rights reserved. For permission to reuse any of this content visit https://www.bmj.com/company/products-services/rights-and-licensing/permissions/

BMJ Case Report Fellows may re-use this article for personal use and teaching without any further permission.

Become a Fellow of BMJ Case Reports today and you can:

- Submit as many cases as you like

- Enjoy fast sympathetic peer review and rapid publication of accepted articles

- Access all the published articles

- Re-use any of the published material for personal use and teaching without further permission

Customer Service

If you have any further queries about your subscription, please contact our customer services team on +44 (0) 2071111105 or via email at support@bmj.com.

Visit casereports.bmj.com for more articles like this and to become a Fellow 